\title{
Occupational Competence Needs Analysis in Furniture Making Industry
}

\author{
M. Syaom Barliana ${ }^{\mathrm{a}, 1}$, Ilhamdaniah ${ }^{\mathrm{a}}$, Dadang Kurnia ${ }^{\mathrm{b}}$ \\ ${ }^{a}$ Department of Architectural, Indonesia University of Education, Bandung, INDONESIA \\ ${ }^{\mathrm{b}}$ Department of Electrical Engineering, Indonesia University of Education, Bandung, INDONESIA \\ 1aombarli@upi.edu
}

\begin{abstract}
This research project intends to adapt existing methods for the identification of work processes in selected occupations and existing methods for work process analysis in order to draft a toolbox for occupational analysis. The research most likely will include three methods, namely occupational sector analysis, expert workers workshops, and work process analysis. Results from expert workers workshops, based on the discussion and consensus among carpenters in the expert workers workshop and some refinements in terms of language, the core working tasks of a wood furniture worker in Bandung Indonesia are as follows: marketing (promotion), designing, cost calculation and volume estimation, purchasing the materials, furniture shaping/parts assembling, and finishing. The expert worker workshop in this research, despite its fruitful results, has a substantial shortage, namely the workers invited are from the several company. With some modifications in the research methodologies, the methods can be applied in Indonesia, to suit the real condition in the field. For the curriculum development based on the occupational competence needs analysis, the involvement from the formal industry (bigmedium companies are needed).
\end{abstract}

Index Terms - occupational sector analysis, expert workers workshops, work process analysis; furniture industry.

\section{Introduction}

Recently, in the economic-based industry, and sciencebased economy, the country needs high multi skills human resources. Vocational education have very important roles to support that need. Some experts mention strategic roles of vocational education in the relation of economy and human resources. Billet, said that vocational education is serving the economy system and the labor market. Each changes which happen in local, national or global labor market will give implication to the vocational education [1]. Relate to this, Reference [2] highlighting the vocational education is moved by work market need and contribute to the national economy strenghten. According to Burke and Smith, Education and vocational training are aiming to increase the knowledge and skills of community, for personal need, also for working and bigger participation in the large community [3]. Vocational education, can develop the skills of marketable man exceed their function as a production tool.

Thus, it so close relation between vocational education and world of work, than the development of vocational education curricula should based on the world of work need analyse. Reference [4] mentioned, the effective vocational education should connected to the world of work, thus it should be planned based on the work market prediction.

The world of work itself continuing changes dinamicly, in the more complicated context of knowledge, technology, social, economy, politics, and culture. In the middle of movement between old and new world of work, there are a set of main skills to survive and work today, long life education for the future, and being a good active citizens. The main skills, related to Wagner, consist of: critical thingking and problem solving; leading and wide networking colaboration; adaptation; initiative and enterpreuneurships; effective oral and written communication; information access and analysis; curiousity and imagination. [5].

That skills are needed to face and anticipate the future world of work tendency, according to Billet, have characters: non-routine; spesific and also various, intens; conceptual; wisdom; complex, and based on the interaction with others, tools, and artefacts. [6].

Thus the teacher vocational education which supplied by Institute of Teacher's Education or Lembaga Pendidikan Tenaga Kependidikan (LPTK), should preparing prospective teachers or instructures which have profesional competences that meet the study program at Vocational High School. The technology and vocational teacher education and training, at the scholar level which combining academic education and professional, should based on the world of work and industry needs analysis. Thus, the professional teacher competency should accomodate the aspiration of workplace and industry.

Reality, there are still less number of teachers and lecturers in Indonesia that have methodological skill to analyse world of work and competence terms in work place, and also tranform it into the curricula of vocational education which responsive to the world of work need. Meanwhile, that is an important competency. The teachers of Vocational High School are produced by LPTK, than it is necessary that the lecturers in LPTK have the same competency. However, it is mandatory, that teacher educators have such methodologies at hand and master them in order: To include the respective knowledge about requirements at work places in TVET teacher education; To include the teaching of the methodologies in TVET teacher education, so that teachers in their future job are able to analyse workplaces and competence requirements; To be able to run research on TVET curriculum development with the purpose to inform national TVET curriculum development; To be able to analyse work places / work processes in order compare competence requirements in TVET at the regional and international level, also with reference to upcoming regional qualification frameworks.

This research project intends to adapt existing methods for the identification of work processes in selected occupations and existing methods for work process analysis in order to draft a toolbox for occupational analysis. As a 
basis, several existing methodologies like occupational analysis as practiced by ITB Bremen, a modified functional analysis approach developed for GIZ some years ago, or even DACUM, will be used in order to create a viable and applicable methodology.[7]. The methodology most likely will include 3 elements, namely occupational sector analysis, expert workers workshops, and work process analysis. (based on skilled workers observation).

The study was conducted in the Regional Cooperation Platform for Vocational Teacher Educational and Training in Asia (RCP) framework, a German funded regional project of the Federal Ministry for International Cooperation and Development (BMZ). The research partners in this topic consist of Indonesia University of Education (UPI, Indonesia) and Tong Ji University (China). Each partner will apply the methodology in a pilot manner in their own countries by analysing two occupations. The occupations should be agreed by the partners in order to be able to compare the results. In this paper, we would like to presenting the Indonesia Country Report is the result of an implementation ofthe methodologies to study the occupational profile and task of wood furniture workers (carpenters) in Bandung, Indonesia.

\section{Research Methodologies}

The procedure of research consisting of four steps: Occupational sector analysis, which summarizes some basic facts and development trends of the (wood) furniture industry in Indonesia; Occupational profile analysis, which resulted from an expert worker workshop. This outlines the occupational profile and elaborate working tasks of a wood furniture worker; Occupational task analysis, which clarify the result from the expert worker workshop. It analyzes and describes the work process and some other major characteristics of the working tasks outlined above.It gives the reader a detailed description about the actual working processes of a wood furniture worker, their basic requirements, tools requirements, working environment, etc.; Methodological reflection and suggestion, which is a summary of the lessons learned in the implementation of three methodologies in research process. Some shortages of this research project implementation are reflected to give input for further methodological revision.

In this case, we invited eight expert carpenters to the workshop. Those carpenters are specializing in the making of furniture, with various materials from wood. They were coming from 4 different companies, all of them are in the scale of home industry (small to medium scale industry). Three of the experts were coming from the Punakawan wood workshop, specializing in the making of furniture for kitchen cabinet, food booth, etc with the basic material from wood, multiplex and other modern finishing material. Two other are coming from the home-based furniture making, experienced in various material such as solid wood and multiplex. Two of the carpenters are coming from the solid wood furnituremaking, called Amrozy Meubel. One carpenter was involved in the furniture-making industry but focus on basic material from wood with rattan as finishing material.

\section{The Research Result}

\section{a. Occupational Sector Analysis}

Ideally the OSA gather the data from existing sources of data and information (e.g. labour market information, job descriptions), surveys of employers and key stakeholders, interviews with a representative sample of employers and key stakeholders, workshops or focus groups with employers and key stakeholders. The occupational sector analysis (OSA) here is mainly based on the secondary data analysis (content analysis) from literature and statistics on the furniture industry in Indonesia. The description are regarding to the general information about the wood furniture industry, the developmental trends and the vocational training that support the sector.

Based on the data from Centre for Industrial Studies (CSIL), the world furniture trade had reached USD 122 billion. China is quite dominating the world market atapproximately USD 45 billion, Vietnam has earned U.S. \$ 4 billion, while Indonesia furniture export is USD 1,7 billion, or less than $2 \%$ of total world global furniture trade. Based on data from the Ministry of Trade, the results of the industrial exports reached U.S.\$ 1.9 billionin 2012. The value increased 10.2 percent from the previous year, which was U.S.\$ 1.7 billion.

In the national market, the local furniture industry still holds $70 \%$ of domestic furniture market. However, market share is threatened by imported furniture from China whose grow threached $200 \%$ per year in the past year. The increase in imported furniture from China that occur each year primarily for lower middle market.

The local furniture business development needs to be improved, not only to meet the local needs, but also to absorb the skilled labor. Their competitiveness to imported furniture products also need to be enhanced. For the export market, the need of skilled labor in the business of furniture making is crucial. Therefore the demand of skilled worker in this business is increasing. For meeting the demand of local market, the skilled worker also needed.

Formal vocational training program that support the labor force for furniture-making industry is vocational secondary high school in building construction expertise, majoring in furniture skill. The training in the sector is also offered by short-term training programs in various training organizations (for example TVET Training Centre) or on the job. Nation wide, there are some vocational school specializing in training wood workers, such as in Centre of Wood Industri (Pusat Industri Kayu/PIKA) Semarang. PIKA has secondary vocational high school, the polytechnic for diploma program in wood industry, and the production unit for commercial furniture making. The information on shortterm training program and on-the-job training in a city, province and country scale is not available.

\section{b. Occupational Profile Analysis}

The occupation selected by UPI and IBB Tongji was carpenter in building construction, specifically in the furniture making industy. Carpentry is a skilled trade in which the primary work performed is the use of wood to construct items as large as buildings and as small as desk drawers.

The occupation chosen for this study was carpenter (cabinet-maker) who are working on the furniture making industry. This occupational profile analysis was conducted through Expert Workers Workshops (EWW). The expert carpenters are invited to attend one day workshop, and the researchers tried to tap their description of occupational expertise trough the steps of expert worker workshop. 


\section{1) Expert Worker Workshop}

The facilitator is one the most crucial factors when implementing EWW. The skills and competencies of the facilitator in terms of technical knowledge and methodological know-how determine the success of the workshop. The facilitators also need to do the preparation of all the worksheets that are needed in the EWW. The experts to participate in the EWW are selected based on their response to our initial invitation to the wood workshops. The experts which gave positive response and voluntarily willing to contribute to the EWW then formally invited to attend the workshop in UPI.

The attending carpenters are the ones that possess experience in the wood furniture-making industry. FPTK UPI invited eight expert carpenters to the workshop. Those carpenters are specializing in the making of furniture, with various materials from wood. They were coming from 4 different companies, all of them are in the scale of home industry (small to medium scale industry). Three of the experts were coming from the Punakawan wood workshop, specializing in the making of furniture for kitchen cabinet, food booth, etc with the basic material from wood, multiplex and other modern finishing material. Two other are coming from the home-based furniture making, experienced in various material such as solid wood and multiplex. Two of the carpenters are coming from the solid wood furnituremaking, called Amrozy Meubel. One carpenter was involved in the furniture-making industry but focus on basic material from wood with rattan as finishing material.

Among the eight workers invited to the workshop, 1 worker has a work experience of nearly 40 years, 1 worker has a work experience of 17 years, 1 workers have worked as wood furniture worker for 10 years, 1 had 8 years of working experience, 2 has approximately5 years' work experience, and 2 has more than 3 years of work experiences as wood furniture worker. The fact that they come from different companies and differ in the type finishing material would enrich the discussion in the workshop.

Objective of EWW: Identify the professional task which constitute an occupation; Get some insight into the content and the complexity of these professional tasks; Get information on which professionals tasks have to be mastered before a learner can proceed to the next professional task.

The workshop was conducted utilizing step by step as stated in the EWW rundown method in RCP P9 research instrument. The description are as follows.

a) Introduction: Objectives of the Expert Worker Workshop; Basic assumption of the EWW; Justification of the selection of participants

b) Personal Occupation History: Participants wrote on the workshop sheet 1: their stages of professional development, from beginning of their career up until become an expert carpenter; describe professional tasks carried out during each of these stages.

c) Participants presented the workshop sheet 1: Moderator asked questions for clarity; Participants marked particularly challenging and qualifying task that was important in shaping their expertise today.

d) Compiling of professional tasks: Participants formed small groups of 3 people. There were 3 groups formed (A, B, C). In each group, the participants identify the professional tasks.
The occupational tasks were written down in the metaplan cards and worksheet 2 . The description in the workshop sheet 2 included the information regarding to tools and methods applied to perform the professional tasks.

a) Presenting and clustering the Professional Tasks: Group A presented one occupational task, the metaplan card of the occupational task is pinned to the board; Moderator asked whether group B and C had similar occupational task, and the similar occupational task were pinned and clustered together; Group B presented one occupational task, the metaplan card of the occupational task is pinned to the board;
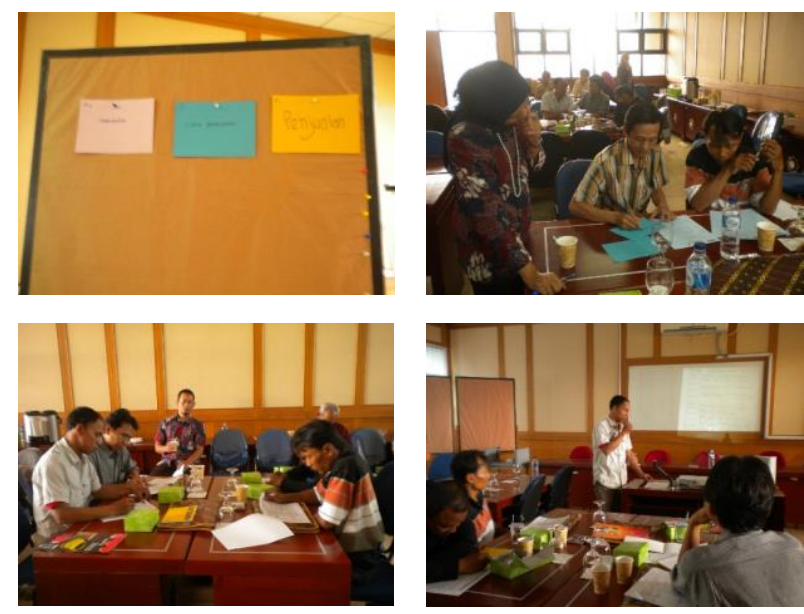

Fig. 1. Expert Worker Workshop Process

Moderator asked whether group A and $\mathrm{C}$ had similar occupational task, and the similar occupational task were pinned and clustered together; Group C presented one occupational task, the metaplan card of the occupational task is pinned to the board; Moderator asked whether group A and B had similar occupational task, and the similar occupational task were pinned and clustered together. The cycle (1-6) repeated until all the cards of each group were presented.

b) The formulation of agreed occupational tasks among group.

c) The discussion of the clustered occupational tasks. Discussion to agree upon the common occupational task performed by the experts in their daily work. The participants agreed on their core occupational tasks.

d) The documentation of occupational tasks. The discussed and agreed occupational tasks was being documented by the facilitator. There were seven core occupational tasks, but the last occupational task of cushioning was only conducted by two carpenters belong to the same factory/workshop which work on chairs. Since most cabinet-makers work on cabinet, kitchenette, desk, bed, and not all of them working on tables and chairs, so the process of cushioning the chairs can be omitted.

After the documentation process completed, the participants took a small break. Furthermore, the participants was expected to fill in the workshop sheet 3, the worksheet listing eight possibilities to assign occupational tasks to different skill levels. The assigning of occupational task to different skill levels was done individually. Each participants must filled in the worksheet 3 . This process was not carried 
out by discussion within group as the $\mathrm{P} 9$ research instrument stated. This is due to the time constraint, since the discussion would took more time.The filled worksheet will be calculated by the researcher later on. The result of worksheet 3 is attached in the appendices of this report.

After the process completed, the facilitator summed and conclude the discussion. The last session was the feedback session, where the carpenters gave feedback of how the workshop had been carried out. This process marks the end of the workshop.

Table 1. Designing professional task as example

\begin{tabular}{|c|c|c|}
\hline $\begin{array}{l}\text { Core Working } \\
\text { Task2 }\end{array}$ & $\begin{array}{l}\text { Title of the professional task } \\
\text { Designing }\end{array}$ & $\begin{array}{l}\text { Duration : } \\
\text { Depending on the } \\
\text { client } \\
\text { Workplace: } \\
\text { In the clients' place, } \\
\text { finished in the } \\
\text { workshop }\end{array}$ \\
\hline \multicolumn{3}{|c|}{$\begin{array}{l}\text { Description of the occupational field of the activity } \\
\text { Prior to designing phase, the designer needs to pay attention to what the } \\
\text { clients demand for their customized furniture, helping them describe } \\
\text { accurately what they want using sketches or illustration, providing the clien } \\
\text { with the previous products that the carpenters had already work on, and } \\
\text { capture the idea of the client through sketches. Discuss projects with } \\
\text { customers, and draw up detailed specifications. Discuss projects with } \\
\text { customers, and draw up detailed specification. The design will be finalized } \\
\text { in the workshop, by utilizing the computerized drawing or refined technical } \\
\text { drawing.Finally draw up detailed specifications. }\end{array}$} \\
\hline \multicolumn{3}{|c|}{ Contents of work and learning } \\
\hline $\begin{array}{l}\text { Objects: } \\
\text { Understanding } \\
\text { requirements of } \\
\text { the client, } \\
\text { determining the } \\
\text { materials and } \\
\text { structure of the } \\
\text { furniture. }\end{array}$ & $\begin{array}{l}\text { Tools: } \\
\text { Pencil, pen and paper, } \\
\text { computer. } \\
\text { Methods: } \\
\text { Dialogue/discuss with client, } \\
\text { guiding clients with words, } \\
\text { understanding the implicit } \\
\text { wishes. } \\
\text { Interact with other carpenters } \\
\text { to allocate work tasks and } \\
\text { share ideas. } \\
\text { Basic measuring. } \\
\text { Design furniture, using } \\
\text { computer-aided drawing } \\
\text { programs. } \\
\text { Draw up detailed } \\
\text { specifications } \\
\text { Organization: } \\
\text { in small companies, often } \\
\text { conducted by the boss or the } \\
\text { carpenter that had already } \\
\text { have some experiences in } \\
\text { designing the furniture. }\end{array}$ & $\begin{array}{l}\text { Demands: } \\
\text { Discussion phase: } \\
\text { Communicative, } \\
\text { sketching skills, } \\
\text { technical knowledge, } \\
\text { knowledge on } \\
\text { materials and furniture } \\
\text { trends. } \\
\text { Designing phase: } \\
\text { The clients demand } \\
\text { that the carpenter can } \\
\text { illustrate the design in } \\
\text { quick sketch, therefore } \\
\text { the sketching skills are } \\
\text { needed. The technical } \\
\text { knowledge of wood, } \\
\text { computer aided } \\
\text { drawing skill, } \\
\text { knowledge on } \\
\text { materials and furniture } \\
\text { trends are also } \\
\text { demanded. }\end{array}$ \\
\hline
\end{tabular}

\section{2) Results from Expert Workers Workshops}

Based on the discussion and consensus among carpenters in the expert workers workshop and some refinements in terms of language, the core working tasks of a wood furniture worker in Bandung Indonesia are as follows: Marketing (Promotion); Designing; . Cost Calculation and Volume Estimation; Purchasing the materials; Furniture shaping/parts assembling; Finishing. Their detailed information is available as follows Table 1.

The process of planning job schedules to plan work tasks and co-ordinate with sub-trades or other parties are not specifically mentioned in this result of EWW. This is mainly done by the owners of the furniture workshops. The carpenters mostly have to meet the certain time-frame to finish one specific furniture order in order to be paid by the owner. The sooner they finish, they will be paid. However, the longer time they need to finish, the later they will be paid, and the amount of money paid will still the same.

The process of quality control was done in almost all core occupational tasks, but mostly in the finishing phase. The experts do not mentioned the quality control as a specific core occupational task. There are not yet written quality standard that has to be met. Mostly it depends on the client and the price of the furniture ordered. There are range of quality of products or materials and it affect the cost of the furniture.

The carpenter still need to do the final assembling while setting the customized furniture in the client's place. The final quality control was done in the client's place, incorporating the demand of the client.

\section{c. Occupational Task Analysis - Work Process Analysis}

The work process analysis was conducted in three wood furniture workshops. The WPA was conducted to verify the process that had been described in the EWW. The interview was conducted with the carpenters while they are performing their daily work in the workshop. Among the workshops visited are Punakawan workshop, Megah Jaya Workshop and Amrozy Meubel Workshop. The difference in work process analysis among the workshops sometimes due to the difference in the finishing materials, the tools that are used, and the working environment of the workshop.

\section{1) Work Process Analysis in Punakawan Workshop}

Punakawan Workshop located in Jalan Gedebage Selatan no 171, Bandung. This is a small furniture workshop, which occupy the workshop area of approximately 30 square meters with naturally ventilated workshop terrace. The working process of core occupational tasks (marketing, designing, cost calculation/volume estimation, purchasing/procurement, producing furniture/assembling, finishing) are performed mainly in this workshop.

\section{2) Clarification of Occupational Task as Described in the Expert Worker Workshop}

Table 2. Clarification of designing occupational task as example

\begin{tabular}{|l|l|}
\hline Occupational task 2: Designing \\
\hline Item & Description \\
\hline Workplace: & $\begin{array}{l}\text { Usually the refined designing and drawing } \\
\text { work takes place in the office/workshop. Using } \\
\text { rough sketches as discussed with client, } \\
\text { Commonly that designing and drawing process } \\
\text { is finished with the assistance of computer } \\
\text { software. }\end{array}$ \\
\hline Business and Work & $\begin{array}{l}\text { Prior to designing phase, the } \\
\text { designer/carpenter/workshop owner have to } \\
\text { discuss projects with customers. The designer } \\
\text { needs to pay attention to what the clients } \\
\text { demand for their customized furniture, helping } \\
\text { them describe accurately what they want using } \\
\text { sketches or illustration, providing the client } \\
\text { with the previous products that the carpenters } \\
\text { had already work on, and capture the idea of } \\
\text { the client through sketches. } \\
\text { Browsing the ideas through literatures, } \\
\text { magazines, flyer, brochure, and online } \\
\text { literatures also become part of this process. }\end{array}$ \\
\hline
\end{tabular}




\begin{tabular}{|l|l|}
\hline Occupational task 2: Designing \\
\hline Item & Description \\
\hline & $\begin{array}{l}\text { Visit the client's place to measure (if it is a } \\
\text { built-in kitchenette or cabinet). } \\
\text { The design will be finalized in the workshop, } \\
\text { by utilizing the computerized drawing or } \\
\text { refined technical drawing.Finally draw up } \\
\text { detailed specifications. }\end{array}$ \\
\hline $\begin{array}{l}\text { Objects of the work } \\
\text { task: }\end{array}$ & $\begin{array}{l}\text { This is done as the service to the customer. The } \\
\text { workshop do not charge the fee for the design } \\
\text { process. }\end{array}$ \\
\hline Tools, methods: & $\begin{array}{l}\text { Paper, sketching pencil, pen, computer aided } \\
\text { drawing. }\end{array}$ \\
\hline Organization of work: & $\begin{array}{l}\text { Performed individually by the carpenter who } \\
\text { has the duty to design and had discussed with } \\
\text { the client. Interact with owner to discuss new } \\
\text { ideas and potential changes. }\end{array}$ \\
\hline $\begin{array}{l}\text { Demands made on } \\
\text { skilled work \& } \\
\text { technology: }\end{array}$ & $\begin{array}{l}\text { The clients requires design that up-to-date with } \\
\text { the trend, meet their needs and } \\
\text { reasonable/affordable price. }\end{array}$ \\
\hline
\end{tabular}

Below are some of the illustration of working process during the work process analysis in the workshop.

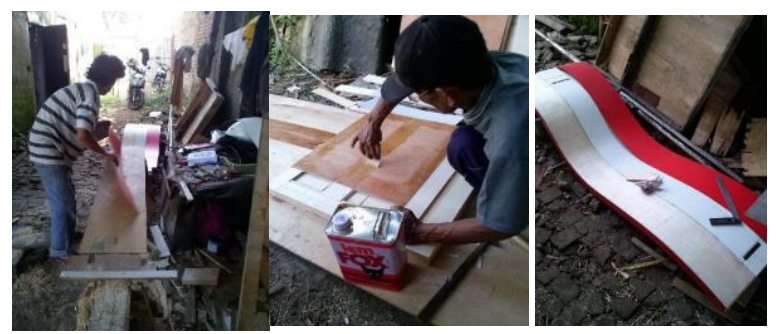

Fig.2. The examples of working process
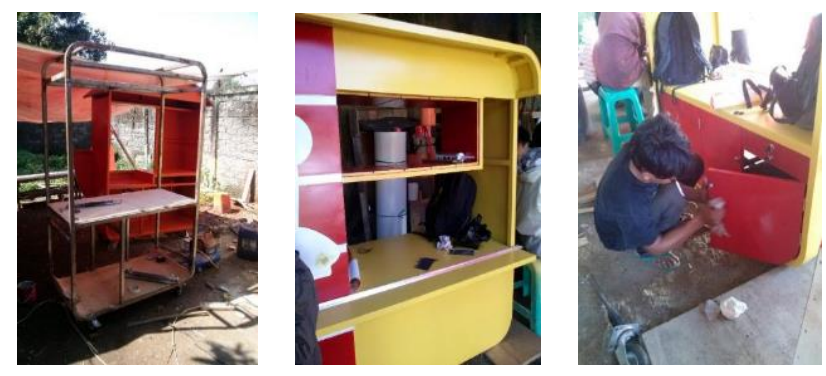

Fig.3. The examples of products from this wood-furniture workshop

\section{Conclusion and Remarks}

Remarks on Occupational Sector Analysis. The data is nationwide. Lack of data on provincial level or municipal level. The data is difficult to obtained, since not properly recorded by the municipal level. Especially the small scale industry do not registered their companies, so that the aggregated data in municipal/city/provincial level is difficult to obtain.

Remarks on Experts' Expertise. Experts that were invited in our EWW mostly gained their expertise through apprenticeship process which did not involve formal vocational trainings. This case is mostly occur in the small scale business industry in cabinet-making, as well as in other wood construction sector. If the experts were coming from the big scale industries, likely the expertise of the experts came from formal vocational training. Learning is done as part of regular work activity or from co-workers working the in the projects. This is done through reading or other forms of self-study at work, on worker's own time, using materials available through work. If the expert carpenters are assigned to train the apprentice in a certain work, there is no record or evaluation reports on apprentices who have been assigned to them on the job. The construction industry is experiencing rapid changes due to technological advancements and a changing regulatory framework. The furniture industry also experiencing the growth and development of trend/styles. Carpenters must incorporate new skills and knowledge of designing, constructing, assembling, new materials and placing a new emphasis on continuous learning.

Remarks on Working Condition in Work Process Analysis. Lack of proper working place condition. Lack of attention to Occupational Health and Safety Regulations as needed to create safe work practices. They do not exactly pay attention and read material safety data sheets (MSDS) carefully to identify the chemical composition of materials, how to use them safely and emergency first-aid procedures. There is concern on energy efficiency, mostly regarding to electricity efficiency. The carpenters/workers do not use time cards to record work hours and times for payroll. The notes is still done manually, or recorded by the owners. It is essential to maintain a job diary to record job information and the relevant details of their day's work such as problems encountered and resolved, hours of work, etc, so that the work can be recorded. There is no written reports for informal meetings or project completion, only a record using the photograph of finished furniture.

Remarks on methodological reflection and suggestion. the expert worker workshop in this research, despite its fruitful results, has a substantial shortage, namely the workers invited are from the several company. with some modifications in the research methodologies, the methods can be applied in indonesia, to suit the real condition in the field. for the curriculum development based on the occupational competence needs analysis, the involvement from the formal industry (big-medium companies are needed). since that formal industry possess the experts, educated, experienced in doing their occupational tasks. they also do the work systematically. the industry also provide with adequate infrastructures, tools to support the work process. the research mainly focused on the application of the method to analyze specific job analysis process. further recommendation to follow up this research is to develop the curriculum based on this methods. implementing the methods for as an approach to develop a curriculum seems to be a comprehensive task by involving all business scales. it is also need to be conducted in various location in indonesia (not only java as center of development), to have a representation of all condition in Indonesia.

\section{Acknowledgment}

We would like to express the deepest appreciation to Director the Regional Cooperation Platform for Vocational Teacher Educational and Training in Asia (RCP) framework, a German funded regional project of the Federal Ministry for International Cooperation and Development (BMZ).

We would like to thank to Dr. Joachim Dittrich as research advisor whose work demonstrated to us that concern for research methodology and curriculum development in TVET and should always transcend academia and provide a quest for our times. 
In addition, a thank you to Director and Staff of Megah Jaya, Punakawan, and Amroji Meubel companies who has helped and parcipated in the expert worker workshop.

\section{Reference}

[1]. Billet S., Changing Work, Work Practice: The Consequences for Vocational Education; in Rupert Maclean, David Wilson, Chris Chinien; International Handbook of Education for the Changing World of Work, Bridging Academic and Vocational Learning: Germany: Springer Science Business Media, 2009

[2]. Pavlova M.\& Munjanganja,L.E. Changing Workplace Requirements. Implications for Education Rupert Maclean, David Wilson, Chris Chinien; International Handbook of Education for the Changing World of Work, Bridging Academic and Vocational Learning: Germany: Springer Science Business Media, 2009

[3]. Burke, G \& Selby Smith C. Economic Perspective on Technical and Vocatioal Education and Training in Australia., Maclean, R. \& Wilson (Eds). International Hanbook of Education for the Changing World of Work, Springer, Dordrecht, 2009

[4]. Pavlova M.\& Munjanganja,L.E. Changing Workplace Requirements: Implications for Education Rupert Maclean, David Wilson, Chris Chinien; International Handbook of Education for the Changing World of Work, Bridging Academic and Vocational Learning: Germany: Springer Science Business Media, 2009

[5]. Wagner T. The Global Achievement Gap. New York: Basic Books, 2008

[6]. Billet S., Changing Work, Work Practice: The Consequences for Vocational Education; in Rupert Maclean, David Wilson, Chris Chinien; International Handbook of Education for the Changing World of Work, Bridging Academic and Vocational Learning: Germany: Springer Science Business Media, 2009

[7]. Dittrich, J.(Ed.). Curriculum Design: From professional tasks to the education and training plan. Institut Technik und Bildung. Bremen: Universität Bremen, 2008 